\title{
Treatment of crystallized-fruit wastewater by UV-A LED photo-Fenton and coagulation-flocculation
}

\author{
Jorge Rodríguez-Chueca a , Carlos Amor a , José R. Fernandes ${ }^{\text {b, c }}$, Pedro B. Tavares a , \\ Marco S. Lucas ${ }^{\text {a, } d, *}$, José A. Peres ${ }^{a}$ \\ a Centro de Química de Vila Real, Departamento de Química, UTAD - Universidade de Trás-os-Montes e Alto Douro, 5000 -801 Vila Real, Portugal \\ b Departamento de Física, UTAD - Universidade de Trás-os-Montes e Alto Douro, 5000-801 Vila Real, Portugal \\ ${ }^{c}$ INESC-TEC, Rua do Campo Alegre, 687, 4169-007 Porto, Portugal \\ ${ }^{\mathrm{d}}$ Environmental Nanocatalysis and Photoreaction Engineering, Department of Chemical Engineering, Loughborough University, Loughborough LE11 3TU, \\ United Kingdom
}

\section{H I G H L I G H T S}

- First report on CFW treatment with UV-A LED photo-Fenton.

- RSM was applied to achieve the optimal conditions for UV-A LED photo-Fenton.

- Combining UV-A LED photo-Fenton and CFD allow achieve a COD removal greater than $80 \%$.

- UV-A LED photo-Fenton and CFD increases the CFW biodegradability $\left(\mathrm{BOD}_{5} / \mathrm{COD}>0.4\right)$.

\section{A R T I C L E I N F O}

\section{Article history:}

Received 18 July 2015

Received in revised form

19 October 2015

Accepted 23 November 2015

Available online 12 December 2015

Handling Editor: Jun Huang

\section{Keywords:}

Biodegradability

Coagulation/flocculation

Crystallized-fruit wastewater

Photo-Fenton

UV-A LED

\begin{abstract}
A B S T R A C T
This work reports the treatment of crystallized-fruit effluents, characterized by a very low biodegradability $\left(\mathrm{BOD}_{5} / \mathrm{COD}<0.19\right)$, through the application of a UV-A LED photo-Fenton process. Firstly, a BoxBehnken design of Response Surface Methodology was applied to achieve the optimal conditions for the UV-A LED photo-Fenton process, trying to maximize the efficiency by saving chemicals and time. Under the optimal conditions $\left(\left[\mathrm{H}_{2} \mathrm{O}_{2}\right]=5459 \mathrm{mg} / \mathrm{L} ;\left[\mathrm{Fe}^{3+}\right]=286 \mathrm{mg} / \mathrm{L} ;\right.$ time $\left.>180 \mathrm{~min}\right)$, a COD removal of 45,64 and $74 \%$ was achieved after $360 \mathrm{~min}$, using an irradiance of 23,70 and $85 \mathrm{~W} / \mathrm{m}^{2}$ respectively. Then a combination of UV-A LED photo-Fenton with coagulation-flocculation-decantation attained a higher COD removal (80\%), as well as almost total removal of turbidity (99\%) and total suspended solids (95\%). Subsequent biodegradability of treated effluents increased, allowing the application of a biological treatment step after the photochemical/CFD with $85 \mathrm{~W} / \mathrm{m}^{2}$.
\end{abstract}

(c) 2015 Elsevier Ltd. All rights reserved.

\section{Introduction}

The crystallized-fruit industry annually generates large volumes of wastewater, mainly from several washing and cooking operations of fresh fruits in syrup (water and sugar) as well as the rinsing of tanks, barrels and other equipment. This industrial effluent is characterized by a high seasonal variability, high organic load and

\footnotetext{
* Corresponding author. Environmental Nanocatalysis and Photoreaction Engineering, Department of Chemical Engineering, Loughborough University, Loughborough LE11 3TU, United Kingdom.

E-mail addresses: m.p.lucas@lboro.ac.uk, mlucas@utad.pt (M.S. Lucas).
}

unpleasant odour. Conventional treatments available, such as biological processes, in Municipal Wastewater Treatment Plants (MWWTP) are susceptible to several constraints due to the low biodegradability and high organic load of this wastewater.

In order to overcome the limitations of biological processes, physical-chemical treatments have been envisaged as promising alternatives to efficiently remove organic matter, suspended solids and turbidity (Amor et al., 2015). In this context, Advanced Oxidation Processes (AOPs), like $\mathrm{H}_{2} \mathrm{O}_{2} / \mathrm{UV}-\mathrm{C}$, heterogeneous photocatalysis, photo-Fenton and $\mathrm{H}_{2} \mathrm{O}_{2} / \mathrm{O}_{3}$, have been proposed as valuable approaches for water and wastewater treatment (Sichel et al., 2007; Polo-López et al., 2011; Lanao et al., 2012; Rodríguez- 
Chueca et al., 2012) due to their efficiency in the generation of hydroxyl radicals (HO'). These highly oxidant species can oxidize almost all organic compounds and inactivate a wide range of microorganisms. AOPs are reported to have been successfully used for the removal of dyes and pigments (Wang et al., 2015); in the treatment of landfill leachates (Cassano et al., 2011; Amor et al., 2015); fresh surface water and drinking water (Mosteo et al., 2009; Lanao et al., 2010); urban wastewater effluents (RodríguezChueca et al., 2014); and also in the paper (Lucas et al., 2012); cork (De Torres-Socías et al., 2013); and agri-food industries (Durán et al., 2012; Chatzisymeon et al., 2013; Velegraki and Mantzavinos, 2015).

Fenton's reagent oxidation is a homogeneous catalytic oxidation process that uses a mixture of hydrogen peroxide and ferrous ions. In an acid environment, the addition of hydrogen peroxide to an aqueous system containing an organic substrate and ferrous ions produces a complex redox reaction (Kuo, 1992; Walling, 1998; Peres et al., 2004). The ferrous ions initiate and catalyze the decomposition of $\mathrm{H}_{2} \mathrm{O}_{2}$, resulting in the generation of hydroxyl radicals, $\mathrm{HO}^{*}$ (Chen and Pignatello, 1997).

The production of $\mathrm{HO}^{*}$ is greatly increased by UV-vis radiation up to a wavelength of $600 \mathrm{~nm}$. Photo-Fenton produces hydroxyl radicals via a series of catalytic cycle reactions with iron $\left(\mathrm{Fe}^{2+}\right.$ and $\left.\mathrm{Fe}^{3+}\right), \mathrm{H}_{2} \mathrm{O}_{2}$, and $\mathrm{UV}$ radiation. The highest photo-Fenton efficiency is found at pH 2.8 (Pignatello et al., 2006), since iron salts precipitate far from this $\mathrm{pH}$ value. These reactions can be summarized as follows:

$\mathrm{Fe}^{2+}+\mathrm{H}_{2} \mathrm{O}_{2} \rightarrow \mathrm{Fe}^{3+}+\mathrm{OH}^{-}+\mathrm{HO}^{\cdot}\left(k=70 \mathrm{M}^{-1} \mathrm{~s}^{-1}\right)$

$\mathrm{Fe}(\mathrm{OH})^{2+}+\mathrm{h} v \rightarrow \mathrm{Fe}^{2+}+\mathrm{HO}^{\bullet}$

Different UV radiation sources to assist photo-Fenton treatments, especially low and medium pressure mercury lamps, have been reported in recent years, but their high operational cost associated with large energy consumption and their toxicity are important drawbacks. In view of this, UV-Light-emitting diodes (LEDs) lamps, which are more efficient and more ecofriendly, present a serious alternative to mercury lamps and solar radiation. Semiconductor LEDs technology are a directional light source with maximum intensity at an angle almost perpendicular to the surface emission. Although at a relatively high cost, LEDs lamps have several advantages when compared to traditional UV lamps - they do not over heat and have a longer lifetime, lower energy consumption and higher efficiency (Rojviroon et al., 2012; Natarajan et al., 2011).

When LEDs lamps are activated, the electrons and holes are directed to $p$ - $n$ junctions, suffering a recombination and emitting light (electroluminescence). This recombination compromises the coupling of electrons and holes become more stable to release excess energy by photon emission. In fact, almost all the electrical energy is converted into light energy (Natarajan et al., 2011). As all emitted photons have approximately the same frequency, this implies that the light is monochromatic, thus the wavelength depends on the semiconductor material used. UV LEDs have been increasingly used as they can be applied in several different processes, such as the degradation of chemicals and inactivation of microorganisms (Natarajan et al., 2011).

The main purpose of this research was to optimize the experimental conditions (reaction time, $\mathrm{Fe}^{3+}$, and $\mathrm{H}_{2} \mathrm{O}_{2}$ dosages) of UV-A LED photo-Fenton treatments by means of a Response Surface Methodology (RSM) model. This optimisation was followed by an evaluation of the combination of a UV-A LED photo-Fenton treatment with a CFD in crystallized-fruit industry wastewater degradation.

\section{Materials and methods}

\subsection{Samples}

Crystallized-fruit wastewater (CFW) samples were collected at a company located in the North of Portugal. This company is the market leader of crystallized-fruit production for baking, jam and quince jelly in Portugal. The production process requires a high amount of water to wash and cook of the fruits.

The main fruits used in the industrial process are pumpkins, carrots, pears, oranges, quinces, apples, cherries and figs. These fruits are conserved in baths of sodium bisulphite solutions before their handling. This processing stage promotes the generation of a high reducer wastewater. The physicochemical characteristics of the crystallized-fruit wastewater are summarized in Table 1 . The large differences observed in the physicochemical parameters, mainly in terms of $\mathrm{pH}$, oxidation potential, $\mathrm{COD}$ and $\mathrm{BOD}_{5}$, of the three different samples are a consequence of: i) the different productive process in each sample time; ii) the elementary operation of the WWTP of the factory, which relied solely on $\mathrm{pH}$ correction with $\mathrm{NaOH}$ and aeration of samples in order to remove the sodium bisulfite used to preserve the fruits.

\subsection{Analytical determinations}

Different physicochemical parameters such as $\mathrm{pH}$, conductivity, redox potential, turbidity, Total Suspended Solids (TSS), Volatile Suspended Solids (VSS), Chemical Oxygen Demand (COD), Total Polyphenols (TP) and Cationic and Anionic concentration were analyzed to characterise the sample. In addition, values of COD, TSS and Turbidity were analyzed during the treatments in order to assess the efficiency of the treatments.

Chemical Oxygen Demand was measured according to the 410.4 Method of the Environmental Protection Agency of USA, using a $\mathrm{HACH}$ DR/2400 portable spectrophotometer. BOD $_{5}$ was checked and measured according to the 5-Day BOD Test (Standard Method 5210B) using OxiTop ${ }^{\circledR}$ Control respirometer. The $\mathrm{pH}$ and redox potential were determined by a HANNA pH 209 laboratory meter following the Standard Method 4500-H+-B and 2580 respectively, while conductivity was measured by a Crison Basic as indicated in ISO 7888:1985. Turbidity was measured according to ISO 7027:1999 using a HACH 2100 IS Turbidimeter. Total Suspended Solids (TSS) were measured by spectrophotometry according to Standard Method 2540D using a HACH DR/2400 portable spectrophotometer, while Volatile Suspended Solids (VSS) were measured using Standard Method 2540-E. In addition, Total Polyphenols concentration (TP), (mg gallic acid/L), was determined by spectrophotometry using the Folin-Ciocalteu reagent (Merck) (Singleton and Rossi, 1965). UV-vis measurements were performed using a Jasco V-530 UV/VIS spectrophotometer. Finally, the anionic analysis was carried out according to D4327 and D6919-09 ASTM International Standards for anions and cations respectively, using a Dionex AS modelo ICS-3000 Detector Chromatography for anions determination, while for cationic determination, a Thermo Scientific Ice 3000 Series AA Spectrometer and an ATI Unicam Solaar 939 Atomic Absorption Spectrometer for the concentrations of $\mathrm{mg} / \mathrm{L}$ and $\mu \mathrm{g} / \mathrm{L}$ were used respectively.

\subsection{Reagents}

Fenton and photo-Fenton treatments were carried out with different dosages of $\mathrm{FeCl}_{3} \cdot 6 \mathrm{H}_{2} \mathrm{O}$ (Merck) and $\mathrm{H}_{2} \mathrm{O}_{2}(30 \% \mathrm{w} / \mathrm{w}$, Panreac) used as reagent grade. In addition, $\mathrm{H}_{2} \mathrm{SO}_{4}$ (Scharlau) and $\mathrm{NaOH}\left(\mathrm{BDH}\right.$ Prolabo ${ }^{\mathbb{R}}$ ) aqueous solutions were applied for $\mathrm{pH}$ adjustment. $\mathrm{Na}_{2} \mathrm{SO}_{3}$ (Merck) was used to quench the hydroxyl 
Table 1

Physicochemical characteristics of crystallized-fruit wastewater.

\begin{tabular}{|c|c|c|c|}
\hline \multirow[t]{2}{*}{ Parameter } & \multicolumn{3}{|l|}{ Values } \\
\hline & Sample A (02/2014) & Sample B (05/2014) & Sample C (07/2014) \\
\hline pH (Sorensen scale) & 9.78 & 3.50 & 6.95 \\
\hline $\mathrm{E}^{\mathrm{o}}(\mathrm{mV})$ & -140 & 212 & 17 \\
\hline Conductivity $(\mu \mathrm{S} / \mathrm{cm})$ & 3820 & 8304 & 8578 \\
\hline Turbidity (NTU) & 410 & 359 & 633 \\
\hline Total suspended solids (mg/L) & 1100 & 1420 & 1850 \\
\hline Volatile suspended solids (mg/L) & 125 & 265 & - \\
\hline $\mathrm{COD}\left(\mathrm{mg} \mathrm{O}_{2} / \mathrm{L}\right)$ & 22932 & 20902 & 35369 \\
\hline $\mathrm{BOD}_{5}(\mathrm{mg} \mathrm{O} / \mathrm{L})$ & 1400 & 3300 & 6600 \\
\hline Biodegradability $\left(\mathrm{BOD}_{5} / \mathrm{COD}\right)$ & 0.06 & 0.16 & 0.19 \\
\hline Polyphenols (mg gallic acid/L) & 142 & 403 & 384 \\
\hline Absorbance at $254 \mathrm{~nm}$ (diluted 1:25) & 0.265 & 0.323 & 0.409 \\
\hline Absorbance at $254 \mathrm{~nm}$ (diluted 1:10) & 0.539 & 0.708 & 0.927 \\
\hline Hardness $\left(\mathrm{mg} \mathrm{CaCO}_{3} / \mathrm{L}\right)$ & 135 & 219 & 228 \\
\hline Chloride $\left(\mathrm{mg} \mathrm{Cl}^{-} / \mathrm{L}\right)$ & 824 & 1073 & 1281 \\
\hline Nitrite $\left(\mathrm{mg} \mathrm{NO}_{2}^{-} / \mathrm{L}\right)$ & 453 & 0.07 & 0.01 \\
\hline Nitrate $\left(\mathrm{mg} \mathrm{NO}_{3}^{-} / \mathrm{L}\right)$ & 168 & 49.3 & 88.8 \\
\hline Phosphates $\left(\mathrm{mg} \mathrm{PO}_{4}{ }^{3-} / \mathrm{L}\right)$ & 143 & n.d. & n.d. \\
\hline Sulphates $\left(\mathrm{mg} \mathrm{SO}_{4}{ }^{2-} / \mathrm{L}\right)$ & 80.5 & 272.5 & n.d. \\
\hline Calcium $\left(\mathrm{mg} \mathrm{Ca}^{2+} / \mathrm{L}\right)$ & 36.1 & 48.6 & 39.2 \\
\hline Iron $\left(\mathrm{mg} \mathrm{Fe}^{2+} / \mathrm{L}\right)$ & 87 & 3.0 & 2.2 \\
\hline Magnesium (mg $\left.\mathrm{Mg}^{2+} / \mathrm{L}\right)$ & 10.8 & 23.8 & 31.6 \\
\hline Potassium $\left(\mathrm{mg} \mathrm{K}^{+} / \mathrm{L}\right)$ & 2850 & 222 & 224 \\
\hline Sodium $\left(\mathrm{mg} \mathrm{Na}^{+} / \mathrm{L}\right)$ & 901 & 2766 & 2632 \\
\hline Aluminium $\left(\mathrm{mg} \mathrm{Al}^{3+} / \mathrm{L}\right)$ & 7.2 & 28.9 & 37.1 \\
\hline Arsenic ( $\mu \mathrm{g} \mathrm{As} / \mathrm{L})$ & 7 & 46 & 62 \\
\hline Copper $\left(\mu \mathrm{g} \mathrm{Cu}^{2+} / \mathrm{L}\right)$ & 81 & 21 & 25 \\
\hline Manganese (mg $\left.\mathrm{Mn}^{2+} / \mathrm{L}\right)$ & 46 & 0.16 & 0.08 \\
\hline
\end{tabular}

radicals action before analyses. The titanium (IV) oxysulfate solution (Riedel-de Haën, Germany) was used as received in order to analyse the concentration of $\mathrm{H}_{2} \mathrm{O}_{2}$. Finally, different inorganic $\left(\mathrm{FeSO}_{4} \cdot 7 \mathrm{H}_{2} \mathrm{O}, \mathrm{FeCl}_{3} \cdot 6 \mathrm{H}_{2} \mathrm{O}, \mathrm{Al}_{2}\left(\mathrm{SO}_{4}\right)_{3}, \mathrm{Ca}(\mathrm{OH})_{2}\right.$ and aluminium chlorohydrate (Kemira Ibérica) and organics (QT100 and QTH100 (Grove Chemicals)) coagulants were used in coagulation-flocculation processes.

\subsection{Radiation source}

All experiments were carried out in a batch mode lab-scale prototype reactor and illuminated with two different UV-A LED systems. The first UV LED photo-system applied was a matrix of 96 Indium Gallium Nitride (InGaN) LEDs lamps (Roithner RLSUV370E), with an illuminated area of $11 \times 7 \mathrm{~cm}^{2}$. These LED lamps had a light peak emission wavelength at $370 \mathrm{~nm}$, and the nominal consumption of each LED lamp was $80 \mathrm{~mW}$ operating at $20 \mathrm{~mA}$. The total optical power emitted was approximately $100 \mathrm{~mW}$, depending on the root mean square (RMS) current intensity supplied. The system irradiance was measured using a UV enhanced Si-photodetector (ThorLabs PDA155) in a configuration that replicated the one used in the photoreactor. In this system the output optical power was controlled using a pulse width modulation (PWM) circuit. The RMS current intensity was measured with a multimeter (UniVolt DT-64).

The second UV LED system was developed with 12 InGaN LED lamps (Roithner APG2C1-365E LEDS) with a light peak emission wavelength at $365 \mathrm{~nm}$. The nominal consumption of each LED lamp was $1.4 \mathrm{~W}$, for an applied current of $350 \mathrm{~mA}$. The output optical power was controlled by maintaining the forward current constant using a power MOSFET in six different current settings.

The treatments were carried out in two UV-A LED photosystems. The first one used a RMS current intensity of $240 \mathrm{~mA}$, corresponding to a UV irradiance of $23 \mathrm{~W} / \mathrm{m}^{2}$ and a photon flux of $5.53 \times 10^{-7} \mathrm{E} / \mathrm{s}$. In the second photo-system current intensities of
262 and $327 \mathrm{~mA}$ were applied, corresponding to an UV irradiance of 70 and $85 \mathrm{~W} / \mathrm{m}^{2}$, respectively, and a photon flux of $1.68 \times 10^{-6}$ and $2.04 \times 10^{-6 \mathrm{E} / \mathrm{s}}$, respectively.

Fig. S1 (Supplementary material) shows the two UV-A LED photosystems and a diagram of the set-up experiments.

\subsection{Experimental procedure}

The different experiments were carried out in a batch UV-A LED photoreactor. The $\mathrm{pH}$ was adjusted to 3 , using $\mathrm{H}_{2} \mathrm{SO}_{4}$ and a $209 \mathrm{pH}$ Meter from Hanna Instruments. Then, the $\mathrm{FeCl}_{3} \cdot 6 \mathrm{H}_{2} \mathrm{O}$ dosage (60-300 $\mathrm{mg} / \mathrm{L}$ ) was added to the effluent. Hydrogen peroxide (200-5500 $\mathrm{mg} / \mathrm{L}$ ) was directly added to the photoreactor at the beginning of each experiment. During each experiment the samples were withdrawn at different intervals and analysed. The $\mathrm{H}_{2} \mathrm{O}_{2}$ concentration was measured in a spectrophotometer (Jasco V-530) at $410 \mathrm{~nm}$ according to DIN $38409 \mathrm{H} 15$, based on the formation of a yellow complex from the reaction of titanium (IV) oxysulphate with $\mathrm{H}_{2} \mathrm{O}_{2}$. The titanium (IV) oxysulphate method displays a detection limit of $0.1 \mathrm{mg} / \mathrm{L}$. The signal was read after $5 \mathrm{~min}$ incubation time against a $\mathrm{H}_{2} \mathrm{O}_{2}$ standard curve from 0.1 to $100 \mathrm{mg} / \mathrm{L} \mathrm{H}_{2} \mathrm{O}_{2}$. The $\mathrm{Na}_{2} \mathrm{SO}_{3}$ was added to water samples for the elimination of residual hydrogen peroxide. Temperature and $\mathrm{pH}$ were also monitored. Total polyphenols were monitored using the Folin-Ciocalteau method (Singleton and Rossi, 1965). The chemical oxygen demand (COD), biochemical oxygen demand $\left(\mathrm{BOD}_{5}\right)$ and total and volatile solids were monitored according to the Standard Methods (Eaton et al., 2005). Moreover, the total iron concentration was measured using the phenanthroline method. Each sample was mixed with $1 \mathrm{~mL}$ of 1,10-phenanthroline $(1 \mathrm{~g} / \mathrm{L})$ and $1 \mathrm{~mL}$ of buffer solution according to ISO 6332 regarding the assessment of dissolved $\mathrm{Fe}^{2+}$ and total iron $\left(\mathrm{Fe}_{\text {total }}\right)$ concentrations. The coloured complex formed was measured with a spectrophotometer (Jasco V$530)$ at $510 \mathrm{~nm}$. The concentrations of $\mathrm{Fe}^{2+}$ and $\mathrm{Fe}_{\text {total }}$ were determined using dedicated calibration curves. The temperature 
remained constant around $21^{\circ} \mathrm{C}$. All assays were carried out in duplicates and results are presented as mean \pm standard deviation. Previous studies of coagulation-flocculation-decantation optimization carried out in our research work (data not shown) demonstrated that the best coagulant was $\mathrm{FeCl}_{3} \cdot 6 \mathrm{H}_{2} \mathrm{O}$ at neutral $\mathrm{pH}(\mathrm{pH}$ 7 ). In addition, the best yields, mainly in terms of suspended solids and turbidity removal, were observed when CFD was performed after photo-Fenton treatments, because in this way, sludge generated (mainly composed of ferric hydroxides) is removed after the Fenton treatments. Therefore, the CFD processes were carried out at $\mathrm{pH}$ 7, after the photo-Fenton treatment and using the remaining iron.

A Jar-Test (ISCO) was used to first produce a rapid agitation (200 rpm) for $3 \mathrm{~min}$, where destabilization of the colloids occurred. This was followed by a slow agitation (40 rpm) period of $15 \mathrm{~min}$. Finally, to promote the formation and precipitation of flocs, a decantation period of 60 min was allowed.

\subsection{Experimental design}

A Box-Behnken design was employed to evaluate the effect of different parameters on the UV-A LED photo-Fenton treatment of crystallized-fruit effluents, such as $\mathrm{H}_{2} \mathrm{O}_{2}\left(\mathrm{mg} / \mathrm{L}, \mathrm{X}_{1}\right)$ and $\mathrm{Fe}^{3+}(\mathrm{mg} / \mathrm{L}$, $\mathrm{X}_{2}$ ) concentration, and reaction time ( $\mathrm{min}, \mathrm{X}_{3}$ ). For this study, 15 UV-LED photo-Fenton experiments were performed. The levels considered for the Box-Behnken design are listed in Table 2a. The treatment schedule (Table $2 \mathrm{~b}$ ) was arranged to allow an appropriate regression model. All experiments were carried out in triplicate. Three replicates at the center of the design were used (Experiments 1, 4, and 15). Experiments were randomized to maximize the efforts of unexplained variability in the observed response due to external factors.

Table 2

(a) Symbols and coded factor levels for the considered variables. (b) Box-Behnken design: effect of operational variables on COD removal yield $\left(\left[\mathrm{H}_{2} \mathrm{O}_{2}\right]=1100-5500 \mathrm{mg} / \mathrm{L} ;\left[\mathrm{Fe}^{3+}\right]=60-300 \mathrm{mg} / \mathrm{L} ;\right.$ reaction time $\left.=30-180 \mathrm{~min}\right)$.

\begin{tabular}{|c|c|c|c|c|c|c|}
\hline \multicolumn{7}{|l|}{ (a) } \\
\hline \multirow{2}{*}{\multicolumn{2}{|c|}{ Independent variables }} & \multirow{2}{*}{\multicolumn{2}{|c|}{ Coded }} & \multicolumn{3}{|l|}{ Levels } \\
\hline & & & & -1 & 0 & 1 \\
\hline \multirow{3}{*}{\multicolumn{2}{|c|}{$\begin{array}{l}{\left[\mathrm{H}_{2} \mathrm{O}_{2}\right](\mathrm{mg} / \mathrm{L})} \\
{\left[\mathrm{Fe}^{3+}\right](\mathrm{mg} / \mathrm{L})} \\
\text { Reaction time (min) }\end{array}$}} & \multirow{3}{*}{\multicolumn{2}{|c|}{$\begin{array}{l}X_{1} \\
X_{2} \\
X_{3} \\
\end{array}$}} & 1100 & 3300 & 5500 \\
\hline & & & & 60 & 180 & 300 \\
\hline & & & & 30 & 105 & 180 \\
\hline \multicolumn{7}{|l|}{ (b) } \\
\hline \multirow[t]{3}{*}{ Assay } & \multicolumn{4}{|l|}{ Coded level } & \multirow{2}{*}{\multicolumn{2}{|c|}{$\begin{array}{l}\text { Response values } \\
\text { COD removal (\%) } \\
\end{array}$}} \\
\hline & \multirow{2}{*}{$\overline{\frac{\left[\mathrm{H}_{2} \mathrm{O}_{2}\right](\mathrm{mg} / \mathrm{L})}{\mathrm{X}_{1}}}$} & \multirow{2}{*}{\multicolumn{2}{|c|}{$\frac{\left[\mathrm{Fe}^{3+}\right](\mathrm{mg} / \mathrm{L})}{\mathrm{X}_{2}}$}} & \multirow{2}{*}{$\frac{\text { Time }(\mathrm{min})}{\mathrm{X}_{3}}$} & & \\
\hline & & & & & Observed & Predicted \\
\hline $1^{\mathrm{a}}$ & 3300 & 180 & & 105 & 24.45 & 22.40 \\
\hline 2 & 3300 & 60 & & 180 & 26.27 & 24.22 \\
\hline 3 & 5500 & 180 & & 30 & 10.23 & 7.88 \\
\hline $4^{\mathrm{a}}$ & 3300 & 180 & & 105 & 20.36 & 22.40 \\
\hline 5 & 5500 & 60 & & 105 & 16.59 & 19.03 \\
\hline 6 & 5500 & 180 & & 180 & 42.05 & 41.66 \\
\hline 7 & 1100 & 300 & & 105 & 23.86 & 21.42 \\
\hline 8 & 5500 & 300 & & 105 & 31.12 & 31.42 \\
\hline 9 & 3300 & 60 & & 30 & 0.86 & 0.77 \\
\hline 10 & 1100 & 180 & & 30 & 14.01 & 14.40 \\
\hline 11 & 3300 & 300 & & 30 & 6.74 & 8.79 \\
\hline 12 & 1100 & 60 & & 105 & 19.90 & 19.60 \\
\hline 13 & 1100 & 180 & & 180 & 23.35 & 25.70 \\
\hline 14 & 3300 & 300 & & 180 & 30.33 & 30.42 \\
\hline $15^{\mathrm{a}}$ & 3300 & 180 & & 105 & 22.40 & 22.40 \\
\hline
\end{tabular}

a Central points.

\subsection{Statistical analysis}

The coefficients corresponding to the model equation were obtained using Statgraphics Centurion XV.I. (StatPoint Technologies Inc., Warrenton, VA, USA). The analysis of variance (ANOVA) in order to determine any significant difference $(P<0.05)$ was carried out using the SPSS 21.0 software package (LEAD Technologies, Inc., Chicago, USA).

\section{Results and discussion}

\subsection{UV-A LED photo-Fenton optimization by Response Surface Methodology}

The present study was conducted to evaluate the optimal conditions for the removal of COD present in a crystallized fruit effluent (Table 1, sample $\mathrm{C}$ ) through photo-Fenton treatment assisted with UV-A LED radiation $\left(23 \mathrm{~W} / \mathrm{m}^{2}\right)$. Nowadays, the high number of variables that affect photo-Fenton treatments, such as $\mathrm{pH}$, temperature, radiation source, reaction time or dosages of $\mathrm{H}_{2} \mathrm{O}_{2}$, and $\mathrm{Fe}^{3+} / \mathrm{Fe}^{2+}$ are well-known (Pignatello et al., 2006). Similarly, it is widely accepted that the optimal $\mathrm{pH}$ for Fenton and photo-Fenton reactions ranges from 2.5 to 3.5 , since all iron added to water is dissolved at this value, increasing the formation of hydroxyl radicals (Pignatello et al., 2006). Thus, all treatments in this study were carried out at $\mathrm{pH} 3$ to obtain the higher yield in terms of COD removal.

The assessment of the percentage of COD removal was made throughout a range of UV-A LED photo-Fenton conditions $(\mathrm{n}=15)$ based on distinct combinations of $\mathrm{H}_{2} \mathrm{O}_{2}$ concentration, $\mathrm{Fe}^{3+}$ concentration, and reaction time. The results of the 15 runs are shown in Table 2 b. This table includes the experimental design, as well as the observed and predicted values for the considered variable, and the percentage of COD removal. Two preliminary rounds of analytical assessment were performed in order to obtain the adequate range for the considered factors: $\mathrm{H}_{2} \mathrm{O}_{2}$ concentration $\left(\mathrm{X}_{1}\right.$ : $1100-5500 \mathrm{mg} / \mathrm{L}), \mathrm{Fe}^{3+}$ concentration $\left(\mathrm{X}_{2}: 60-300 \mathrm{mg} / \mathrm{L}\right)$ and reaction time $\left(\mathrm{X}_{3}: 30-180 \mathrm{~min}\right)$. The mismatch regarding the optimal values of the ranges considered in the two first rounds could have been due to a conditioning effect exerted by each factor on others and this situation prompted us to enlarge the ranges to obtain optimal values. The range of $\mathrm{H}_{2} \mathrm{O}_{2}$ and $\mathrm{Fe}^{3+}$ concentrations were consistent with those previously assayed in the treatment of agroindustrial effluents by other authors (Dogruel et al., 2009; Durán et al., 2011). With respect to $\mathrm{H}_{2} \mathrm{O}_{2}$ concentration, the reaction rate increases in parallel to the augment of hydrogen peroxide dosage because of the concentration of hydroxyl radicals. However, an excessive dosage of $\mathrm{H}_{2} \mathrm{O}_{2}$ may cause an adverse effect (Wang and Lemley, 2001; Maezono et al., 2011). Thus, the optimal dosage of $\mathrm{H}_{2} \mathrm{O}_{2}$ depends on the physico-chemical characteristics of the effluent and the dosage of iron (Cassano et al., 2011). Additionally, Fenton and photo-Fenton reaction rate increases with high iron concentrations due to the higher generation of hydroxyl radicals (Malato et al., 2009), although with a certain concentration of iron, the efficiency of the reaction decreases or scavenger effects can occur. For this reason a $\mathrm{Fe} / \mathrm{H}_{2} \mathrm{O}_{2}$ ratio as small as possible is desirable in an attempt to avoid possible recombination between both and, thereby reduce the production of iron complexes. Consequently, the interconnection between factors involved in the Fenton and photo-Fenton reaction encourages the evaluation of optimal concentrations of $\mathrm{H}_{2} \mathrm{O}_{2}$ and iron to maximize the COD removal.

The quadratic model achieved permitted the adjustment of theoretical values of COD removal to observed values with a low deviation (Table 2b), suggesting a successful application of the 
Response Surface Methodology as an optimization procedure. In the present study, the model employed was observed to be useful enough to predict COD removal yields without any further experiment.

The regression coefficients of intercept, linear, quadratic, and interaction terms of the model were calculated using the least square method. The effect of the linear, quadratic or interaction coefficients on the response was studied via an analysis of variance (ANOVA) (Table 3). The degree of significance of each factor is represented by its $P$ value, which indicates that the regression models for COD removal was statistically relevant - with a level of significance ranging from $P<0.0001$ to $P<0.0165$. The models did not display significant lack of fit $(P>0.05)$. Thus, these statistical parameters indicated well-fitting models for the described variables. These statistical analyses revealed that the most important variable for COD was the reaction time $\left(\mathrm{X}_{3}\right)(P<0.001)$, whilst secondary variation can be attributed to the $\mathrm{Fe}^{3+}$ concentration $\left(\mathrm{X}_{2}\right)$ and the combination of $\mathrm{H}_{2} \mathrm{O}_{2}$ and reaction time $\left(\mathrm{X}_{1} \mathrm{X}_{2}\right)$ (both $P<0.05$ ) (Table 3).

The response surface plots obtained further supported the relative contribution to the optimal condition for COD removal of each variable evaluated (Fig. 1), and were confirmed by the value of the coefficient of each factor obtained in the polynomial equation (Equation (3)). Moreover, the regression coefficient $\left(\mathrm{R}^{2}\right)$ for this method was 0.973, which means that the model matches the COD removal adequately.

$$
\begin{aligned}
\mathrm{Y}= & 8.91847-0.00895875 \mathrm{X}_{1}+0.0755896 \mathrm{X}_{2}+0.174102 \mathrm{X}_{3} \\
& +7.04976 \cdot 10^{-7} \mathrm{X}_{1}^{2}+0.0000100095 \mathrm{X}_{1} \mathrm{X}_{2} \\
& +0.0000340606 \mathrm{X}_{1} \mathrm{X}_{3}-0.000204716 \mathrm{X}_{2}^{2} \\
& -0.0000505556 \mathrm{X}_{2} \mathrm{X}_{3}-0.000605407 \mathrm{X}_{3}^{2}
\end{aligned}
$$

Optimal conditions concerning the three variables studied were achieved for the treatment of effluent $\mathrm{C}$ (Table 1). Thus, the optimal dosages of $\mathrm{H}_{2} \mathrm{O}_{2}$ and $\mathrm{Fe}^{3+}$ were 5459 and $286 \mathrm{mg} / \mathrm{L}$, respectively. However, to obtain higher COD removal, an optimal reaction time higher than 180 min could be expected.

\subsection{UV-A LED photo-Fenton}

As mentioned in Table 1, due to the low $\mathrm{BOD}_{5} / \mathrm{COD}$ ratio and the reducer behaviour of these effluents, a combination of photoFenton and CFD was chosen as the best alternative to increase the biodegradability of the effluent, suspended solids and turbidity removal. Different UV-A LED photo-Fenton treatments were carried out using the optimal conditions obtained through the RSM $\left(\mathrm{H}_{2} \mathrm{O}_{2}=5459 \mathrm{mg} / \mathrm{L} ; \mathrm{Fe}^{3+}=286 \mathrm{mg} / \mathrm{L}\right.$; time $\left.>180 \mathrm{~min}\right)$. These optimal conditions were applied to the two UV-A LED photosystems at pH 3 during 360 min Fig. 2a shows the COD removal after the Fenton and photo-Fenton treatment was carried out in the first UV-A LED photo-system with an irradiance of $23 \mathrm{~W} / \mathrm{m}^{2}$. As can be observed in Fig. 2a, photo-Fenton treatment reached a COD removal rate of around $45 \%$ after $360 \mathrm{~min}$. The level of COD removal

Table 3

Corresponding $F$-values and $P$-values for selected responses for each obtained coefficient.

\begin{tabular}{llllllllll}
\hline Variable & $\mathrm{X}_{1}$ & $\mathrm{X}_{2}$ & $\mathrm{X}_{3}$ & $\mathrm{X}_{1} \mathrm{X}_{1}$ & $\mathrm{X}_{1} \mathrm{X}_{2}$ & $\mathrm{X}_{1} \mathrm{X}_{3}$ & $\mathrm{X}_{2} \mathrm{X}_{2}$ & $\mathrm{X}_{2} \mathrm{X}_{3}$ & $\mathrm{X}_{3} \mathrm{X}_{3}$ \\
\hline F-value & 5.53 & 12.56 & 126.29 & 5.34 & 3.47 & 15.7 & 3.99 & 0.1 & 5.32 \\
$P$-value & n.s. & $*$ & $* * *$ & n.s. & n.s. & $*$ & n.s. & n.s. & n.s. \\
\hline
\end{tabular}

X1: $\mathrm{H}_{2} \mathrm{O}_{2}(\mathrm{mg} / \mathrm{L}) ; \mathrm{X} 2: \mathrm{Fe}^{3+}(\mathrm{mg} / \mathrm{L}) ; \mathrm{X} 3$ : Reaction time (min). n.s.: Non-significant. Significant at ${ }^{*} P<0.05$ and ${ }^{* * *} P<0.001$.
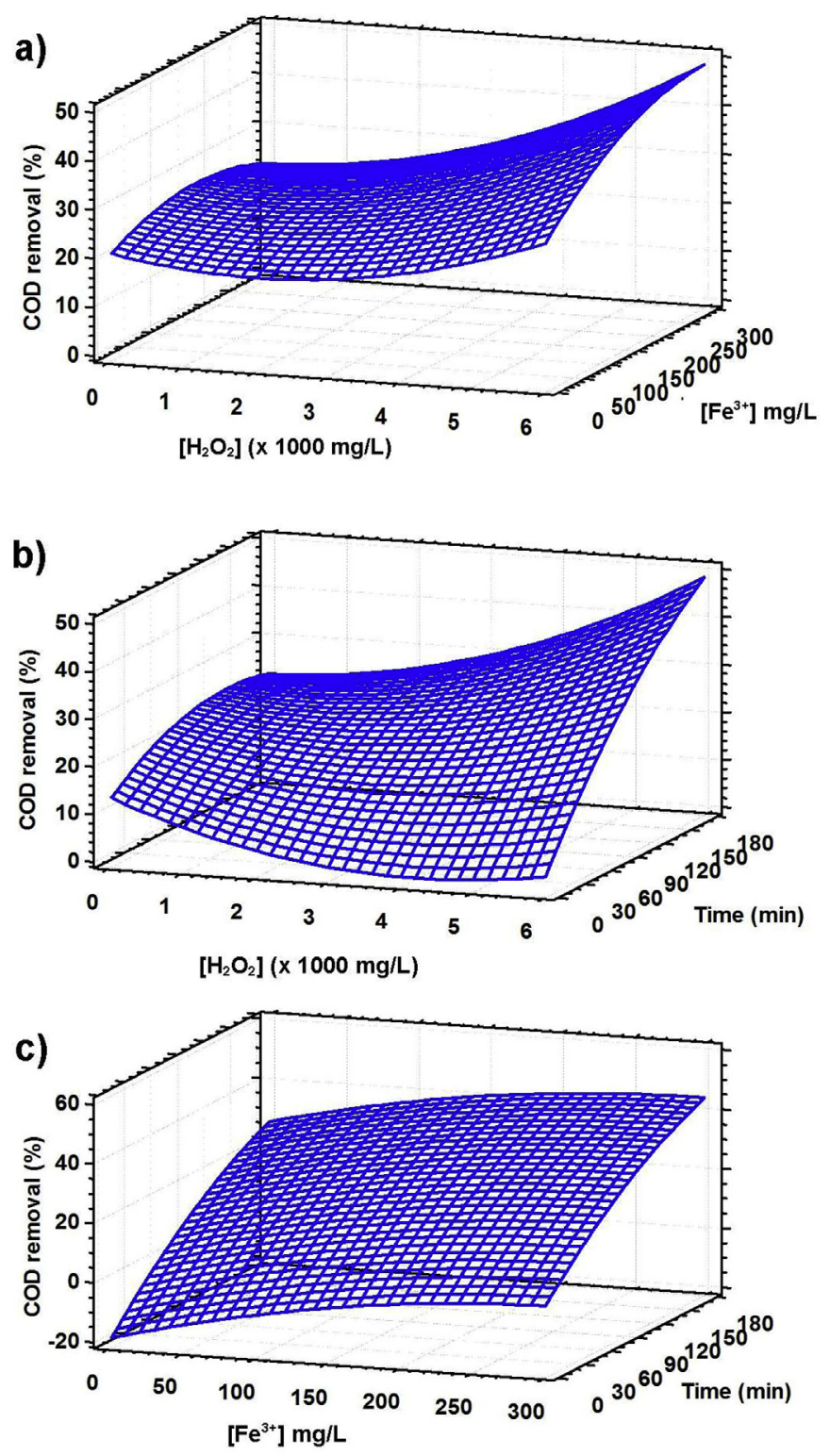

Fig. 1. Response-surface plot showing the effect of $\mathrm{H}_{2} \mathrm{O}_{2}, \mathrm{Fe}^{3+}$, and reaction time on COD removal from crystallized-fruit effluents.

reached contrasts with the results obtained by Fenton reagent, which only afforded a degradation of $13 \%$ at the end of the treatment. In addition, as can be seen in Fig. 2a, UV-A LED irradiation assays were also carried out. From the data, it can be observed that no changes occurred after 360 min of irradiation.

In order to increase the amount of COD removal from the crystallized-fruit industry effluents, a more powerful UV-A LED photo-system was applied. This second UV-LED photo-system was characterized by a higher irradiance under the same current intensity, with the same electric consumption. Therefore, with a current intensity of around $240 \mathrm{~mA}$, an irradiance of $70 \mathrm{~W} / \mathrm{m}^{2}$ was achieved. Additionally, in order to use the maximum capacity of the second UV-LED photo-system, a current intensity of $85 \mathrm{~W} / \mathrm{m}^{2}$ was applied to the effluent. Fig. 2b shows the COD removal in the crystallized fruit effluent after the application of the photo-Fenton treatment with the second UV-A LED system using the optimal conditions reached in the RSM. As shown in Fig. 2b, a higher COD removal (74\%) was achieved with $85 \mathrm{~W} / \mathrm{m}^{2}$. This value is slightly 

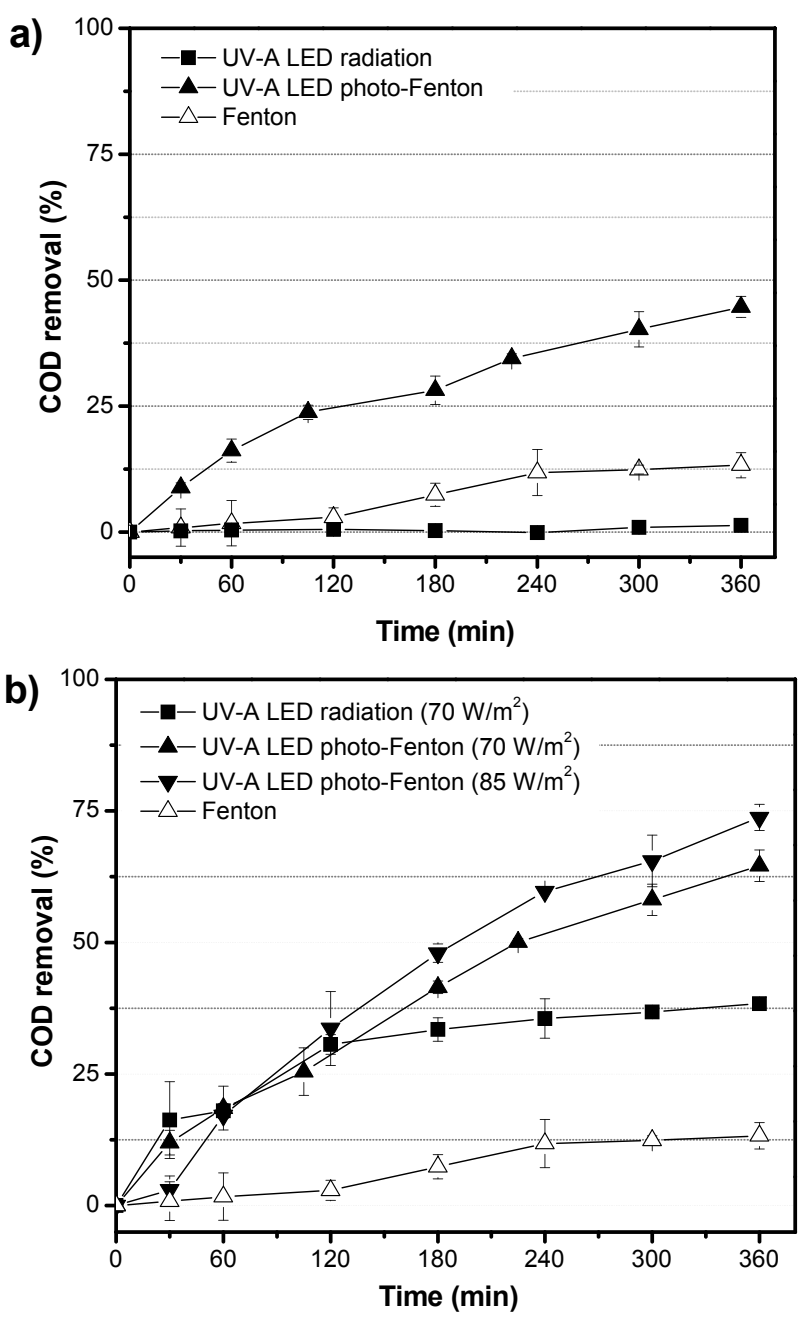
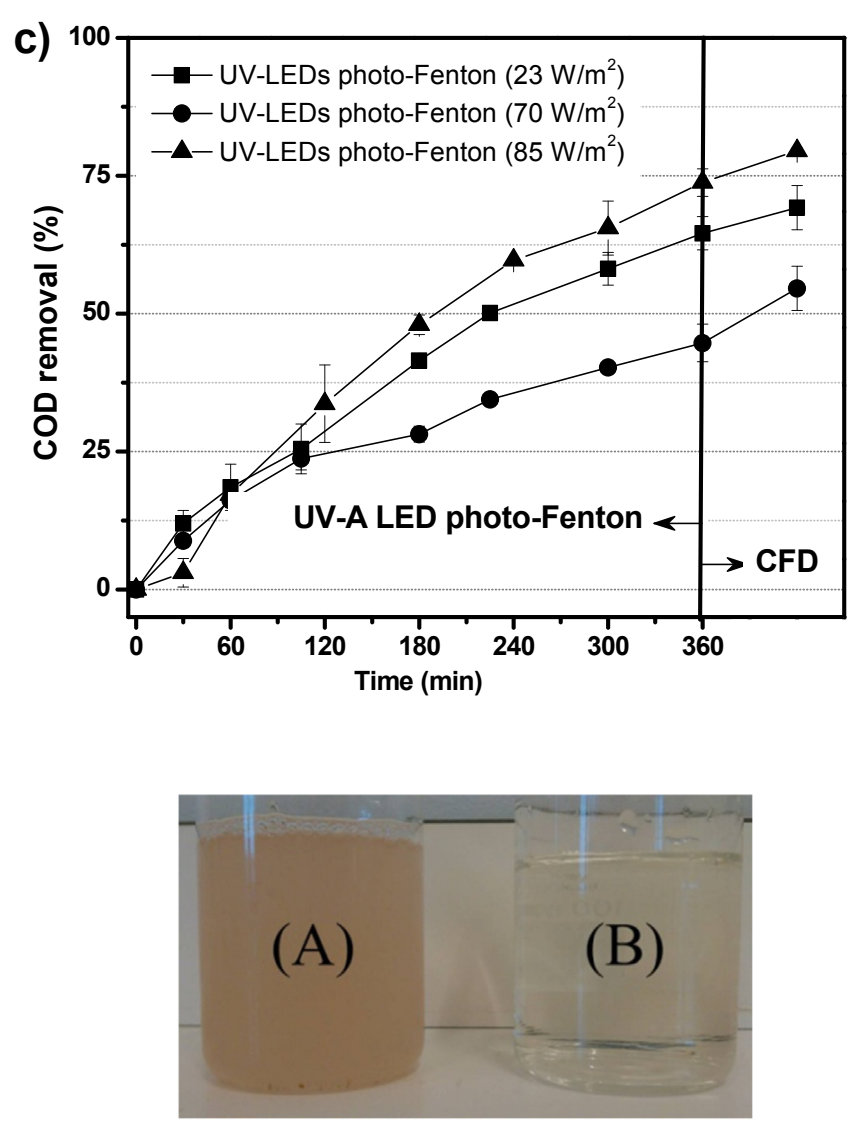

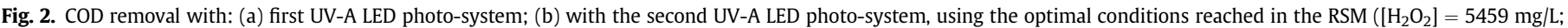
$\left[\mathrm{Fe}^{3+}\right]=286 \mathrm{mg} / \mathrm{L}$; reaction time $>180 \mathrm{~min}$ ); (c) combined UV-A LED photo-Fenton/CFD processes.

higher than that obtained with an irradiance of $70 \mathrm{~W} / \mathrm{m}^{2}$, which was only $65 \%$. Both values are much higher than that obtained in the Fenton treatment, in the absence of a UV-A LED irradiance (13\%). On the other hand, control assays with UV-A LED irradiation and $\mathrm{H}_{2} \mathrm{O}_{2} / \mathrm{UV}-\mathrm{A}$ LED irradiation were carried out in order to check the effect of the different variables independently. In both cases, a final COD reduction of $38 \%$ was reached after $360 \mathrm{~min}$. These results mean that the combination of hydrogen peroxide with UV-A irradiation does not have an oxidation effect over the effluent, since the degradation curve is similar to that obtained in the experiment performed in the absence of $\mathrm{H}_{2} \mathrm{O}_{2}$. Therefore, all the increased reduction of organic matter is a consequence of UV-A LED irradiation. On the other hand, it is necessary to take into account the amount of consumed hydrogen peroxide in photo-Fenton treatments in comparison to the blank assays. In both photo-Fenton treatments (70 and $85 \mathrm{~W} / \mathrm{m}^{2}$ ), hydrogen peroxide was totally consumed at $120 \mathrm{~min}$, and for this reason this oxidant reagent was added again at the initial concentration in order to maintain a constant concentration until the end of the reaction. Thus, approximately $22 \mathrm{~g} / \mathrm{L}$ of $\mathrm{H}_{2} \mathrm{O}_{2}$ was consumed in the treatment carried out with $70 \mathrm{~W} / \mathrm{m}^{2}$. Whilst, approximately up to $29 \mathrm{~g} / \mathrm{L}$ of hydrogen peroxide, was consumed in the treatment with a higher irradiance. As can be observed in Fig. 2b, there are small differences in the first 120 min of degradation curves for both photo-Fenton assays and UV-A LED irradiation and $\mathrm{H}_{2} \mathrm{O}_{2} /$ UV-A LED irradiation, indicating that this sampling point is coincident with the consumption of the initially added hydrogen peroxide $\left(5.4 \mathrm{~g} / \mathrm{L}\right.$ of $\left.\mathrm{H}_{2} \mathrm{O}_{2}\right)$. This means that the first minutes of reaction, due to the high organic load in the effluent, the main effects on the degradation of organic matter are related to the effect of irradiation and to a lesser extent associated with the hydroxyl radicals generated in photoFenton treatment. As the reaction proceeds, the organic load decreases and a higher amount of hydroxyl radicals are formed, causing the consumption of hydrogen peroxide and the advance in the organic matter degradation.

Durán et al. (2011) reported values of COD removal of 59\% after $120 \mathrm{~min}$ in juice effluents with $5800 \mathrm{mg} / \mathrm{L}$ of $\mathrm{H}_{2} \mathrm{O}_{2}$ and $40 \mathrm{mg} / \mathrm{L} \mathrm{Fe}^{3+}$. This result is considerably higher than that shown in Fig. 2. However, it is necessary to take into account important differences between the two studies. Firstly, the effluent studied by Durán et al. (2011), had an initial COD value of $1260 \mathrm{mg} \mathrm{O}_{2} / \mathrm{L}$, much lower than that studied in this research $\left(30000-35000 \mathrm{mgO}_{2} / \mathrm{L}\right)$. Secondly, photo-Fenton treatments carried out by Durán et al. (2011) were assisted with UV-C radiation (low pressure mercury lamp) emitting at $\lambda=190-280 \mathrm{~nm}$. In contrast, UV-A radiation from LEDs lamps was used to assist photo-Fenton treatments in the present research. Velegraki and Mantzavinos (2015) reported a COD removal of around $80 \%$ of winery effluents, after $210 \mathrm{~min}$, through solar photo-Fenton carried out in CPC reactors. To obtain this value an $\mathrm{H}_{2} \mathrm{O}_{2}$ : $\mathrm{COD}$ ratio of 1.7 was used. This ratio is almost three times higher than the ratio, 
(0.6), used to treat the crystallized-fruit effluents which were the object of this study. Thus, despite the complexity of the water matrix treated in the present study (higher COD concentration and reducer behaviour with negative values of redox potential), a similar COD removal to that obtained by Velegraki and Mantzavinos (2015) was achieved, together with a higher effectiveness of $\mathrm{H}_{2} \mathrm{O}_{2}$, which enabled the treatment of higher amounts of COD with the same or lower doses of hydrogen peroxide.

After the UV-A LED photo-Fenton treatments, a coupled CFD stage was carried out in order to increase the COD removal and to reduce the amount of total suspended solids and the turbidity in the treated sample. With this objective, different inorganic and organic coagulants were tested (data not shown). After studying the results obtained with the different coagulants, a coagulation-flocculation-decantation stage at $\mathrm{pH} 7$ using the remaining iron $\left(\left[\mathrm{Fe}_{\text {total }}\right] \approx 325 \mathrm{mg} / \mathrm{L}\right.$ ) from photo-Fenton treatment was carried out. These conditions were selected not only with regards to COD and total suspended solids and turbidity removal, but also taking into account economic factors in order to transfer the studied treatment at laboratory scale to a real treatment plant inside the crystallized-fruit factory. Fig. 2c shows the COD removal after the coupled treatment (UV-A LED photo-Fenton and CFD) with different UV irradiances $\left(23,70\right.$ and $\left.85 \mathrm{~W} / \mathrm{m}^{2}\right)$. As can be seen in this figure, COD removal of treated effluents increased around $22 \%$, with a final value $54 \%$ in the combined treatment carried out with $23 \mathrm{~W} / \mathrm{m}^{2}$. On the other hand, a slighter increase of around 7\% was observed in those treatments carried out in the second photosystem with 70 and $85 \mathrm{~W} / \mathrm{m}^{2}$ achieving a 69 and $80 \%$ final removal of COD respectively. In addition, not only was organic matter removed, but high removal of turbidity and suspended solids was also achieved after the coagulation-flocculation stage. Therefore, maximum values of 99 and 95\% were attained for turbidity and total suspended solids removal after both combined treatments were carried out in the second UV-A LED photo-system.

\subsection{Biodegradability enhancement during coupled UV-A LED photo-Fenton and CFD treatments}

A good biodegradability index of treated wastewater is required for the application of a biological process as the last step in a crystallized-fruit wastewater treatment system. The biodegradability index of all the treated samples (after UV-A LED photoFenton and photo-Fenton combined with CFD treatments) as well as raw wastewater, were evaluated according to the $\mathrm{BOD}_{5} / \mathrm{COD}$ ratio. As shown in Fig. 3, effluent biodegradability increases according to the requirement of treatment. As can be observed in Fig. 3 and Table 1, the biodegradability index of the raw wastewater ranges below 0.4 , between 0.06 and 0.19 . Thus it could be considered as non-biodegradable effluent, since 0.4 is the value at which an effluent can be considered as being easily biodegradable (Pulgarin et al., 1999; Metcalf and Eddy, 2002; Esplugas et al., 2004).

The application of photo-Fenton treatment assisted with $23 \mathrm{~W} /$ $\mathrm{m}^{2}$ of UV-A LED radiation slightly increases the biodegradability to 0.27 . This value is still not enough to carry out a conventional biological treatment. However, an increase of the irradiance in the UV-A LED photo-Fenton treatments leads to the enhancement of the organic matter removal and thus an increase in the biodegradability of the treated effluent. Therefore, after the photoFenton treatments with 70 and $85 \mathrm{~W} / \mathrm{m}^{2}$ the biodegradability index of the treated effluent rises to 0.36 and 0.39 , respectively. Although the effluent is near to biodegradability, it can only be considered biodegradable when the ratio exceeds 0.4 . This value is exceeded after the coupling of the UV-A LED photo-Fenton system and a coagulation-flocculation step. For instance, with an irradiance of $70 \mathrm{~W} / \mathrm{m}^{2}$ the treated effluent had a biodegradability ratio of 0.43 , while, with irradiance of $85 \mathrm{~W} / \mathrm{m}^{2}$ the value is 0.56 after the combined treatment. Therefore, effluents, after UV-A LED photoFenton and subsequent CFD treatment, can be directed to a biological treatment stage in order to achieve the total degradation of organic matter. Similar coupling treatments have been reported in our research group and by other authors (Lucas et al., 2007; Silva et al., 2013; Manenti et al., 2014).

To sum up, an effective crystallized-fruit wastewater treatment cycle could begin in a homogenization tank, where, after a $\mathrm{pH}$ adjustment, the UV-A LED photo-Fenton treatment takes place for enough time to degrade the organic matter to approximately $75 \%$. Then, after being led to a secondary tank, the CFD step could be carried out at $\mathrm{pH} 7$, using the remaining iron from photo-Fenton step. During this stage, turbidity and suspended solids would be removed almost completely. To finalise the process, the pre-treated

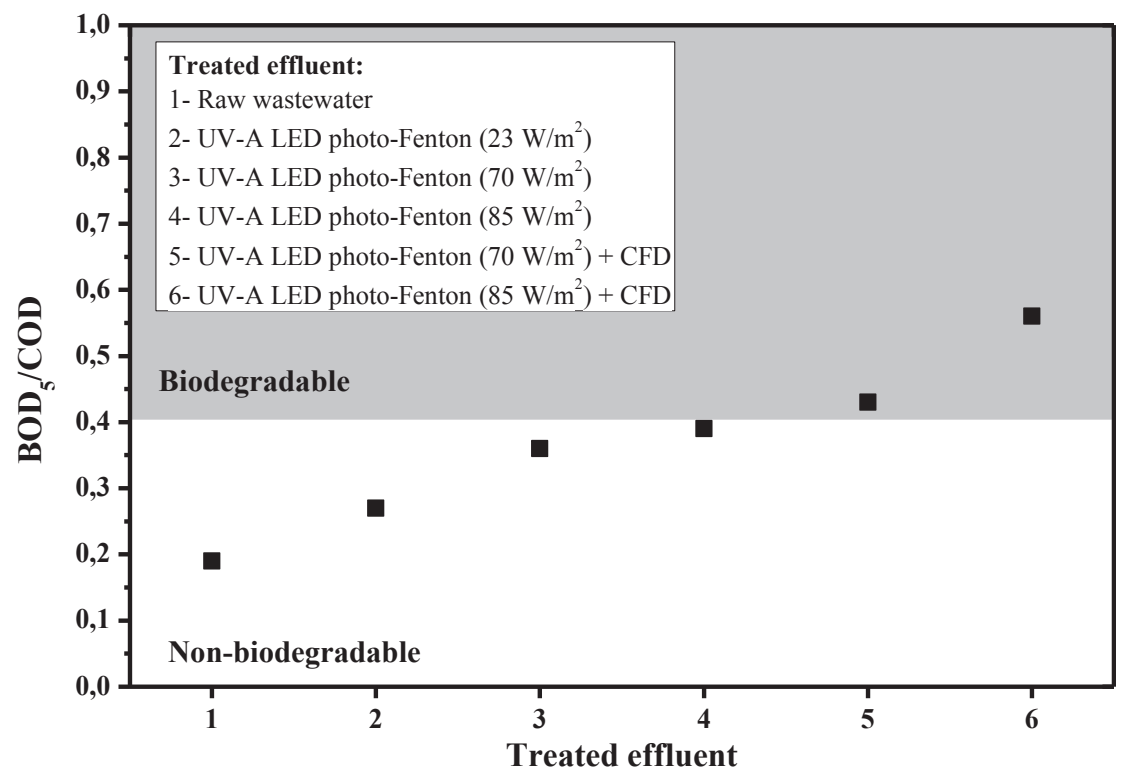

Fig. 3. Evolution of biodegradability index of treated effluents. 
effluent (5000-7000 $\mathrm{mg} \mathrm{O}_{2} / \mathrm{L}$ ) could be subjected to a biological treatment, such as an activated sludge process. The retention time in the activated sludge tank would be dependent upon the treatment goals. If the effluent is to be discharged into a MWWTP, the maximum admissible value of COD is $1000 \mathrm{mg} \mathrm{O} / \mathrm{L}$, so a lower retention time would suffice. Alternatively, if the effluent is to be discharged into a natural water course, a higher retention time in the biological treatment stage would be necessary, since the maximum admissible value is $150 \mathrm{mg} \mathrm{O}_{2} / \mathrm{L}$ (Decreto-Lei no 236/98).

\section{Conclusions}

A Box-Behnken design of Response Surface Methodology was employed to obtain maximum organic matter removal from crystallized-fruit wastewater using a UV-A LED photo-Fenton treatment. The experimental design was effective in estimating the influence of three independent variables critically involved in the removal of COD: $\left[\mathrm{Fe}^{3+}\right],\left[\mathrm{H}_{2} \mathrm{O}_{2}\right]$, and reaction time. In addition, a quadratic model was used to predict response. Evaluation of the best combination of variables to achieve the maximum COD removal $\left(\mathrm{Fe}^{3+}=286 \mathrm{mg} / \mathrm{L} ; \mathrm{H}_{2} \mathrm{O}_{2}=5459 \mathrm{mg} / \mathrm{L}\right.$ and reaction time $>180 \mathrm{~min}$ ) was performed using two UV-A LED photo-systems. The two UV-A LED systems allowed the evaluation of the influence of increasing the irradiance from 23 to $85 \mathrm{~W} / \mathrm{m}^{2}$.

UV-A LED radiation is a serious alternative to conventional UV lamps in terms of ecofriendliness, operational cost, and energy efficiency.

The COD removal increased with the irradiance intensification in the photo-Fenton treatment and $45 \%$ of organic matter was removed with a photo-Fenton with $23 \mathrm{~W} / \mathrm{m}^{2}$. When the second UVA LED system was used (with 70 and $85 \mathrm{~W} / \mathrm{m}^{2}$ ) the removal of COD reached 65 and $74 \%$, respectively.

The coupling of UV-A LED photo-Fenton and CFD increased the removal of COD, to $80 \%$ and, a higher removal of suspended solids (95\%) and turbidity (99\%) was also achieved.

This combined treatment process significantly improved the biodegradability index of the treated effluents, in comparison to that of the raw effluent. Consequently, after UV-A LED photoFenton/CFD treatment, the subsequent effluents can be subjected to conventional biological treatments, such as activated sludge, in order to achieve complete degradation of the effluent's organic matter.

\section{Acknowledgements}

The authors are grateful to the Fundação para a Ciência e a Tecnologia (FCT) for the financial support provided to CQVR through PEst-C/QUI/UI0616/2014 and to the Project INNOFOOD NORTE-07-0124-FEDER-0000029. Marco S. Lucas acknowledges also the funding provided by the European Union's Horizon 2020 research and innovation programme under the Marie SklodowskaCurie grant agreement No 660969.

\section{Appendix A. Supplementary material}

Supplementary material related to this article can be found at http://dx.doi.org/10.1016/j.chemosphere.2015.11.092.

\section{References}

Amor, C., De Torres-Socías, E., Peres, J.A., Maldonado, M.I., Oller, I., Malato, S. Lucas, M.S., 2015. Mature landfill leachate treatment by coagulation/flocculation combined with Fenton and solar photo-Fenton processes. J. Hazard. Mater. 286, $261-268$.

Cassano, D., Zapata, A., Brunetti, G., Del Moro, G., Di Iaconi, C., Oller, I., Malato, S., Mascolo, G., 2011. Comparison of several combined/integrated biological-AOPs setups for the treatment of municipal landfill leachate: minimization of operating costs and effluent toxicity. Chem. Eng. J. 172 (1), 250-257.

Chatzisymeon, E., Foteinis, S., Mantzavinos, D., Tsoutsos, T., 2013. Life cycle assessment of advanced oxidation processes for olive mill wastewater treatment. J. Clean. Prod. 54, 229-234.

Chen, R., Pignatello, J., 1997. Role of quinone intermediates as electron shuttles in Fenton and photoassisted Fenton oxidations of aromatic compounds. Environ. Sci. Technol. 31, 2399-2406.

De Torres-Socías, E., Fernández-Calderero, I., Oller, I. Trinidad-Lozano, M.J. Yuste, F.J., Malato, S., 2013. Cork boiling wastewater treatment at pilot plant scale: comparison of solar photo-Fenton and ozone $\left(\mathrm{O}_{3}, \mathrm{O}_{3} / \mathrm{H}_{2} \mathrm{O}_{2}\right)$. Toxicity and biodegradability assessment. Chem. Eng. J. 234, 232-239.

Decreto-Lei nº. 236/98, de 1 de Agosto. Diário da República - I Série-A. nº 176-1-81998.

Dogruel, S., Olmez-Hanci, T., Kartal, Z., Arslan-Alaton, I., Orhon, D., 2009. Effect of Fenton's oxidation on the particle size distribution of organic carbon in olive mill wastewater. Water Res. 43 (16), 3974-3983.

Durán, A., Monteagudo, J.M., Carnicer, A., 2011. Photo-Fenton mineralization of synthetic apple-juice wastewater. Chem. Eng. J. 168 (1), 102-107.

Durán, A., Monteagudo, J.M., Carnicer, A. San Martín, I., Serna, P., 2012. Solar photodegradation of synthetic apple juice wastewater: process optimization and operational cost study. Sol. Energy Mater. Sol. Cells 107, 307-315.

Eaton, A.D., Clesceri, L.S., Rice, E.W., Greenberg, A.E., Franson, M.A.H., 2005, Standard Methods for the Examination of Water and Wastewater, twenty-first ed. APA-AWWA-WEF.

Esplugas, S., Contreras, S., Ollis, D.F., 2004. Engineering aspects of the integration of chemical and biological oxidation: simple mechanistic models for the oxidation treatment. J. Environ. Eng. 130 (9), 967-974.

Kuo, W.G., 1992. Decolorizing dye wastewater with Fenton's reagent. Water Res. 26 (7), 881-886.

Lanao, M., Ormad, M.P., Goñi, P., Miguel, N., Mosteo, R., Ovelleiro, J.L., 2010. Inactivation of Clostridium perfringens spores and vegetative cells by photolysis and $\mathrm{TiO}_{2}$ photocatalysis with $\mathrm{H}_{2} \mathrm{O}_{2}$. Sol. Energy 84 (4), 703-709.

Lanao, M., Ormad, M.P., Mosteo, R., Ovelleiro, J.L., 2012. Inactivation of Enterococcus sp. by photolysis and $\mathrm{TiO}_{2}$ photocatalysis with $\mathrm{H}_{2} \mathrm{O}_{2}$ in natural water. Sol. Energy 86, 619-625.

Lucas, M.S., Dias, A.A., Sampaio, A., Amaral, C., Peres, J.A., 2007. Degradation of a textile reactive Azo dye by a combined chemical-biological process: Fenton's reagent-yeast. Water Res. 41 (5), 1103-1109.

Lucas, M.S., Peres, J.A., Amor, C., Prieto-Rodríguez, L., Maldonado, M.I., Malato, S. 2012. Tertiary treatment of pulp mill wastewater by solar photo-Fenton. J. Hazard. Mater. 225-226, 173-181.

Maezono, T., Tokumura, M., Sekine, M., Kawase, Y., 2011. Hydroxyl radical concentration profile in photo-Fenton oxidation process: generation and consumption of hydroxyl radicals during the discoloration of azo-dye Orange II. Chemosphere $82,1422-1430$

Malato, S., Fernández-Ibáñez, P., Maldonado, M.I., Blanco, J., Gernjak, 2009. Decontamination and disinfection of water by solar photocatalysis: recent overview and trends. Catal. Today 147, 1-59.

Manenti, D.R., Módenes, A.N., Soares, P.A., Espinoza-Quiñones, F.R. Boaventura, R.A.R., Bergamasco, R., Vilar, V.J.P., 2014. Assessment of a multistage system based on electrocoagulation, solar photo-Fenton and biological oxidation processes for real textile wastewater treatment. Chem. Eng. J. 252, 120-130.

Metcalf, Eddy, 2002. Wastewater Engineering: Water and Reuse. McGraw-Hill, Inc. New York.

Mosteo, R., Miguel, N., Martín-Muniesa, S., Ormad, M.P., Ovelleiro, J.L., 2009. Evaluation of trihalomethane formation potential in function of oxidation processes used during the drinking water production process. J. Hazard. Mater. 172 (2-3) 661-666.

Natarajan, K., Natarajan, T.S., Bajaj, H.C., Tayade, R.J., 2011. Photocatalytic reactor based on UV-LED/TiO 2 coated quartz tube for degradation of dyes. Chem. Eng. J 178, 40-49.

Peres, J.A.S., Carvalho, L.H.M., Boaventura, R.A.R., Costa, C.A.V., 2004. Characteristics of p-hydroxybenzoic acid oxidation using Fenton's reagent. J. Environ. Sci. Health A 39, 1-17.

Pignatello, J.J., Oliveros, E., MacKay, A., 2006. Advanced oxidation processes for organic contaminant destruction based on the Fenton reaction and related chemistry. Crit. Rev. Environ. Sci. Technol. 36, 1-84.

Polo-López, M.I., Fernández-Ibáñez, P., Ubomba-Jaswa, E., Navntoft, C., GarcíaFernández, I., Dunlop, P.S.M., Schmid, M., Byrne, J.A., McGuigan, K.G., 2011 Elimination of water pathogens with solar radiation using an automated sequential batch CPC. J. Hazard. Mater. 196, 16-21.

Pulgarin, C., Invernizzi, M., Parra, S., Sarria, V., Polania, R., Péringer, P., 1999. Strategy for the coupling of photochemical and biological flow reactors useful in mineralization of biorecalcitrant industrial pollutants. Catal. Today 54, $341-352$.

Rodríguez-Chueca, J., Mosteo, R., Ormad, M.P., Ovelleiro, J.L., 2012. Factorial experimental design applied to Escherichia coli disinfection by Fenton and photoFenton processes. Sol. Energy 86, 3260-3267.

Rodríguez-Chueca, J., Polo-López, M.I., Mosteo, R., Ormad, M.P., Fernández Ibáñez, P., 2014. Disinfection of real and simulated urban wastewater effluents using a mild solar photo-Fenton. Appl. Catal. B Environ. 150-151, 619-629.

Rojviroon, T., Laobuthee, A., Sirivithayapakorn, S., 2012. Photocatalytic activity of toluene under UV-LED light with $\mathrm{TiO}_{2}$ thin film. Int. J. Photoenergy. http:// 
dx.doi.org/10.1155/2012/898464.

Sichel, C., Blanco, J., Malato, S., Fernández-Ibáñez, P., 2007. Effects of experimenta conditions on E. coli survival during solar photocatalytic water disinfection. J. Photochem. Photobiol. A Chem. 189, 239-246.

Silva, T.F.C.V., Silva, M.E.F., Cunha-Queda, A.C., Fonseca, A., Saraiva, I., Sousa, M.A. Gonçalves, C., Alpendurada, M.F., Boaventura, R.A.R., Vilar, V.J.P., 2013. Multistage treatment system for raw leachate from sanitary landfill combining biological nitrification-denitrification/solar photo-Fenton/biological processes, at a scale close to industrial - biodegradability enhancement and evolution profile of trace pollutants. Water Res. 47 (16), 6167-6186.

Singleton, V.L., Rossi, J.A., 1965. Colorimetry of total phenolics with phosphomolybdic phosphotungstic acid reagents. Am. J. Enol. Vitic. 16, 144-158.
Velegraki, T., Mantzavinos, D., 2015. Solar photo-Fenton treatment of winery effluents in a pilot photocatalytic reactor. Catal. Today 240, 153-159.

Walling, C., 1998. Intermediates in the reactions of Fenton type reagents. Acc. Chem. Res. 31 (4), 155-157.

Wang, S., Guan, Y., Wang, L., Zhao, W., He, H., Xiao, J., Yang, S., Sun, C., 2015. Fabrication of a novel bifunctional material of $\mathrm{BiOI} / \mathrm{Ag}_{3} \mathrm{VO}_{4}$ with high adsorption-photocatalysis for efficient treatment of dye wastewater. Appl. Catal. B Environ. 168-169, 448-457.

Wang, Q. Lemley, A.T., 2001. Kinetic model and optimization of 2,4-D degradation by anodic treatment. Environ. Sci. Technol. 42 (3-4), 219-224. 